Review

\title{
Use of edible films and coatings in cheese preservation: Opportunities and challenges
}

\author{
Maria J. Costa $^{\mathrm{a}}$, Luís C. Maciel ${ }^{\mathrm{a}}$, José A. Teixeira ${ }^{\mathrm{a}}$, António A. Vicente ${ }^{\mathrm{a}}$, Miguel A. Cerqueira ${ }^{\mathrm{b}, *}$ \\ a Centre of Biological Engineering, University of Minho, Campus de Gualtar, 4710-057 Braga, Portugal. \\ b International Iberian Nanotechnology Laboratory, Av. Mestre José Veiga s/n, 4715-330 Braga, Portugal
}

\section{A R T I C L E I N F O}

\section{Keywords:}

Bio-based polymers

Essential oils

Antimicrobial agents

Shelf life

Edible packaging, dairy

\begin{abstract}
A B S T R A C T
In the last years, there has been a growing interest in the use of edible materials in food packaging. The cheese industry is clearly one of the sectors where these materials have a good opportunity for application, as shown by the recent developments on edible coatings and films for cheese. Edible coatings and films, besides its edibility, can be used to reduce weight loss and prevent the microbiological spoilage through the control of oxygen and carbon dioxide exchange rate and as a carrier of antimicrobial compounds. This review summarizes the recent results on edible films and coatings for cheese, the main developments and the main future perspectives for the application of these materials in the cheese industry.
\end{abstract}

\section{Introduction}

Cheese is an ancient food product that can be prepared from different types of milk. It is very diverse in textures, aromas, flavours and shapes, and often makes part of humans' regular diet, due to its composition (high amount of protein, calcium, minerals and vitamins). The consumption of cheese has increased significantly over the years across the world and, in consequence, cheese industry has now evolved into a global business where research has an important role on the increase of shelf-life and promotion of cheese products' quality and safety. One of the main losses during cheese commercialization happens during storage, where the contamination of cheese by bacteria, moulds and yeasts is common, and therefore the development of off-flavours can happen, decreasing the quality of the cheese, mainly when stored without package. Also, the high moisture loss in some types of cheese can be a problem increasing their hardness and leading to undesired organoleptic properties. Different packaging systems have been suggested to solve these problems, including vacuum and modified atmosphere packaging applied in several types of cheese. Nowadays, materials such as polyethylene, polyamide, and polypropylene are normally used.

Coatings have also been used in cheese preservation and packaging. They can act as an individual packaging material but also as an additional protection if used in combination with other packaging materials. The conventional materials used for coating production are petroleumbased (e.g. paraffin wax and polyvinyl chloride) but nowadays with the environmental and sustainability issues as well as legislation restrictions, the use of edible film and coating materials is being exploited, proving to be a very promising possibility since, such as conventional coating materials, allows spoilage prevention, shelf life extension and reduction of water loss. Many studies have been done aiming at evaluating and understanding the effects of edible films and coatings on several types of cheese (Cerqueira et al., 2009; Mastromatteo, Conte, Faccia, Del Nobile, \& Zambrini, 2014; Ollé Resa, Gerschenson, \& Jagus, 2012). Edible films and coatings can act as carriers of antimicrobial agents and bring several advantages against conventional coatings, such as better spreading, diffusivity and solubility (Ramos et al., 2012).

This review presents an overview of the existing studies about edible films and coatings for cheese preservation. The materials used in the development of edible films and coatings are reviewed, and the antimicrobial agents used are presented. Edible films and coatings application methods in cheeses are also discussed and, finally, relevant commercial applications and patents are presented.

\section{Edible films and coatings for cheese}

Cheese has a complex composition due to the many biological and biochemical reactions that occur from production to storage, influencing its physical, sensorial and chemical characteristics, such as texture, flavour and colour (Robertson, 2006). The intensive growth of yeasts, moulds and bacteria may occur on cheese surface due to the external environmental conditions during handling and storage, which considerably reduce cheese quality and demands for the development of tailored packaging materials to avoid spoilage (Fajardo et al., 2010; Kampf \& Nussinovitch, 2000; McSweeney, Ottogalli, \& Fox, 2004).

\footnotetext{
* Corresponding author.

E-mail address: miguel.cerqueira@inl.int (M.A. Cerqueira).
} 
Packaging requirements change according to the cheese type since the maturation rates, water content and mechanical stability will depend on its composition. It has been suggested that fresh cheeses (e.g., cream cheese, soft cheese, and cottage cheese) should be packaged in modified atmosphere containing $\mathrm{N}_{2}$ and/or $\mathrm{CO}_{2}$ instead of $\mathrm{O}_{2}$ (Mannheim \& Soffer, 1996). However, due to the presence of yeasts and bacteria, spoilage can still occur even at low $\mathrm{O}_{2}$ and high $\mathrm{CO}_{2}$ levels (Westall \& Filtenborg, 1998) making modified atmosphere packaging a solution that should be carefully used taking into account these factors. Nevertheless, the factors that should be considered when selecting a packaging material are almost the same for all cheeses, such as permeability to gases, mechanical properties and transparency.

Some of the used materials for cheese packaging, such as polyethylene, polyamide, polypropylene are non-biodegradable and nonedible and can lead to ecological problems as well as be limited by strict legislation about the migration of the materials into the cheese. For coatings, migration can be an issue, since after application on cheese surface and its solidification (by crystallization in the case of waxes and/or by solvent-evaporation) the migration of some of the coating materials into the cheese may occur. These major concerns led the industry to search for new packaging solutions and thereafter an increasing research concerning edible packaging materials (Fajardo et al., 2010). In this context, biopolymers and natural lipids and waxes emerge as an alternative source for the development of new packaging materials. Edible films and coatings based on these materials can guarantee food quality, acting as a semipermeable barrier to oxygen, carbon dioxide and water vapour, allowing the reduction of water loss and maturation rate control (Garcia \& Barret, 2002). In addition, edible films and coatings can be used as carriers of antimicrobial agents and therefore avoid undesired microbial growth on cheese surface (Cerqueira et al., 2009; Cerqueira et al., 2010; Rodriguez-Turienzo, Cobos, \& Diaz, 2012).

Edible films and coatings can be used to improve food quality and safety, mostly through the shelf life extension, but also to maintain flavour, colour, and nutritional value of cheese. In addition, they present other valuable features (Robertson, 2013; Rojas-Grau, SolivaFortuny, \& Martin-Belloso, 2009): they can be consumed with the cheese avoiding the generation of waste, since there is no residual packaging to be disposed of (even if not consumed) as they are biodegradable (Wang, Liu, Holmes, Kerry, \& Kerry, 2007); organoleptic and nutritional properties of cheese can be enhanced, either due to the film/ coating composition which may have beneficial properties by itself, or to their capacity to incorporate components such as flavouring, dyeing or sweetener agents, that are eaten with the coating (Artiga-Artigas, Acevedo-Fani, \& Martín-Belloso, 2017); they can act as a carrier of active ingredients e.g. with antimicrobial and antioxidant properties, and thus promote cheese preservation with simultaneous control of the diffusion rate of those substances into the cheese (e.g., of importance in some countries where the migration of natamycin is limited). These active ingredients can also be incorporated in edible films and coatings through:

- microencapsulation, allowing an efficient retention and a controlled release into the cheese (Cui, Wu, Li, \& Lin, 2016; Embuena et al., 2016);

- multilayers, allowing the use of different materials and thus an improvement of barrier properties and the incorporation of different materials (e.g., lipophilic and hydrophilic active compounds) on cheese (Duan, Park, Daeschel, \& Zhao, 2007);

- application in small cheese portions (e.g. cheese slices), thus acting as an individual packaging for each portion, which is an additional advantage compared to non-edible packaging (Balaguer et al., 2014).

\section{Effect of edible film and coating materials on cheese properties}

The performance of edible films and coatings is dependent on the materials used and their main characteristics (e.g., solubility, density, viscosity, and surface tension) since they will influence barrier, mechanical and optical properties of the coatings. Film and coating materials should be selected according to the type of cheese (i.e., moisture content, matured or fresh) and storage conditions (e.g. temperature and relative humidity). Also the application methods (e.g. spray, immersion, wrapping) should consider the cheese manufacturer requirements, the coating or film formulation and its final use (coating or film) (Martins, Cerqueira, \& Vicente, 2012; Soradech, Nunthanid, Limmatvapirat, \& Luangtana-anan, 2012). Edible films and coatings differ on the way that they are produced and applied. Edible coatings, available in the liquid form, are applied directly in the food surface where after drying a thin layer is formed, while films are dried separately forming a stand-alone material that is then used to cover the food.

Proteins (Ramos et al., 2012b; Rodriguez-Turienzo et al., 2012), polysaccharides (Bourbon et al., 2011; Martins et al., 2012; Pereira, Souza, Cerqueira, Teixeira, \& Vicente, 2010) and lipids (Cerqueira, Souza, Teixeira, \& Vicente, 2012; Fadini et al., 2013) are the most used materials in the development of edible films and coatings for application on cheese (Al-Hassan \& Norziah, 2012). Polysaccharides and proteins present as main advantage their water-solubility, while for lipids and waxes an organic solvent or hot-melting methods, respectively, should be used during application. Another important factor that needs to be considered, if an antimicrobial agent is added to the coating formulation, is the solubility of the antimicrobial agent and its possible interaction with the coating that can affect their performance when applied on cheese products.

Table 1 presents polysaccharides, proteins and lipids used as coatings on different types of cheese, the coating composition and the methodology used for application.

\subsection{Chitosan}

Chitosan is one of the few cationic polysaccharides, and is obtained from crustaceans or fungi (Fajardo et al., 2010). Chitosan is a very attractive material for edible coating due to its antimicrobial properties against bacteria, moulds and yeasts (Rabea, Badawy, Stevens, Smagghe, \& Steurbaut, 2003). Based on that and in their coating and film forming capacity, chitosan-based coatings and films were tested on several types of cheeses aiming at a decrease of microbiological growth and thus an extension of cheese shelf life. It was also used as a carrier of other compounds with antimicrobial capacity. Coma et al. (2002) inoculated ready-to-eat Emmental cheese with Listeria innocua and used a chitosanbased coating at $1 \%(v / v)$ to act as antimicrobial and inhibit pathogen growth. This approach resulted in the total inhibition of L. innocua during $132 \mathrm{~h}$, when the coating was applied on cheese samples of $1 \mathrm{~cm}^{3}$ and incubated at $37^{\circ} \mathrm{C}$. Duan et al. (2007) applied a chitosan coating with $60 \%$ of lysozyme to an aged, low moisture, sliced mozzarella cheese. They observed, after a storage of 14 days at $10{ }^{\circ} \mathrm{C}$, reductions of $1.25 \log$ (CFU/g) of Escherichia coli (3.23 log CFU/g), $1.4 \log (\mathrm{CFU} / \mathrm{g}$ ) of Pseudomonas fluorescens $(2.38 \log \mathrm{CFU} / \mathrm{g}$ ) and $1.35 \log (\mathrm{CFU} / \mathrm{g})$ of $L$. monocytogenes (3.13 log $\mathrm{CFU} / \mathrm{g}$ ), when compared to control samples (4.48, 3.63, $4.48 \log \mathrm{CFU} / \mathrm{g}$, respectively). Other study that also used chitosan as a carrier of antimicrobials was presented by Fajardo et al. (2010) that tested different concentrations of natamycin in a chitosanbased coating. They used immersion as application method (slices of $0.5 \mathrm{~cm}$ thickness of a semi-hard cheese) and observed a decrease of $1.1 \log (\mathrm{CFU} / \mathrm{g})$ of moulds/yeasts (4.96 log CFU/g) after 27 days of storage at $4{ }^{\circ} \mathrm{C}$, using $0.5 \mathrm{mg} / \mathrm{mL}$ of natamycin, when compared to the control (6.06 log $\mathrm{CFU} / \mathrm{g})$. In other example, a coating with chitosan and whey protein concentrate (WPC) as main materials showed to be effective in the shelf life extension of rindless Ricotta cheese during 
Table 1

Examples of polysaccharides, proteins and waxes used for edible coating formation for application on different types of cheese.

\begin{tabular}{|c|c|c|c|c|}
\hline Material used & Types of cheese & Coating/film composition & Application method & Reference \\
\hline \multirow[t]{4}{*}{ Sodium alginate } & Mozzarella & Water and calcium chloride & Dipping/immersion & (Mastromatteo et al., 2014) \\
\hline & & Water and glycerol & $\begin{array}{l}\text { Dipping/immersion } \\
\text { enrobing }\end{array}$ & (Zhong, Cavender, \& Zhao, 2014) \\
\hline & & & Spraying & \\
\hline & & & Electrostatic spraying & \\
\hline \multirow[t]{10}{*}{ Chitosan } & & Water, acetic acid and glycerol & Dipping/Immersion & (Zhong et al., 2014) \\
\hline & & & Enrobing & \\
\hline & & & Spraying & \\
\hline & & & Electrostatic spraying & \\
\hline & Saloio regional & $\begin{array}{l}\text { Water, lactic acid, tween } 80 \text {, glycerol, } \\
\text { sorbitol and corn oil }\end{array}$ & Brushing & (Cerqueira et al., 2009, 2010) \\
\hline & Ricotta & Water and $\mathrm{HCl}$ & Dipping/immersion & $\begin{array}{l}\text { (Di Pierro, Sorrentino, Mariniello, Giosafatto, } \\
\text { \& Porta, 2011) }\end{array}$ \\
\hline & Cheddar & $\begin{array}{l}\text { Water, acetic acid, glycerol and nisin-silica } \\
\text { liposomes or nisin liposomes }\end{array}$ & $\mathrm{N} / \mathrm{A}$ & (Cui et al., 2016) \\
\hline & Goat's milk cheese & $\begin{array}{l}\text { Water, acetic acid, rosemary and oregano } \\
\text { essential oil }\end{array}$ & Dipping/immersion & (Embuena et al., 2016) \\
\hline & Emmental & Aqueos acid solution & Dipping/immersion & (Coma et al., 2002) \\
\hline & $\begin{array}{l}\text { Egyptian soft white } \\
\text { cheese }\end{array}$ & $\begin{array}{l}\text { Water, acetic acid, carboxymethyl cellulose, } \\
\text { zinc oxide nanoparticles }\end{array}$ & Wrapping & $\begin{array}{l}\text { (Youssef, EL-Sayed, EL-Sayed, Salama, \& } \\
\text { Dufresne, 2016) }\end{array}$ \\
\hline \multirow[t]{3}{*}{ Galactomannans } & Saloio regional & Water, glycerol, sorbitol and corn oil & Brushing & (Cerqueira et al., 2009, 2010) \\
\hline & Ricotta & Water, glycerol, and corn oil & Dipping/immersion & $\begin{array}{l}\text { (Martins, Cerqueira, Souza, Avides, \& Vicente, } \\
\text { 2010) }\end{array}$ \\
\hline & Port Salut & Water, glycerol, nisin, natamycin & $\begin{array}{l}\text { Surface contact } \\
\text { Spray }\end{array}$ & (Ollé Resa, Jagus, \& Gerschenson, 2014) \\
\hline Sodium caseinate & Kashar & Water and glycerol & $\begin{array}{l}\text { Immersion } \\
\text { wrapping }\end{array}$ & (Moreira, Pereda, Marcovich, \& Roura, 2011) \\
\hline Acid casein & & $\begin{array}{l}\text { Water, glycerol, calcium chloride and } \\
\text { natamycin }\end{array}$ & Dipping/Immersion & $\begin{array}{l}\text { (Yangılar \& Oğuzhan Yıldız, 2015; Yıldırım, } \\
\text { Gulec, Bayram, \& Yildirim, 2006) }\end{array}$ \\
\hline Zein & & $\begin{array}{l}\text { Ethanol, glycerol, lysozyme, catechin and } \\
\text { gallic acid }\end{array}$ & Wrapping & (Ünalan, Arcan, Korel, \& Yemenicioğlu, 2013) \\
\hline Whey protein & Ricotta & Water, $\mathrm{HCl}$, chitosan & Dipping/Immersion & (Di Pierro et al., 2011) \\
\hline Egg white protein & Lor & $\begin{array}{l}\text { Water, sorbitol, sage essential oil or lemon } \\
\text { balm essential oil }\end{array}$ & Dipping/Immersion & (Kavas \& Kavas, 2014) \\
\hline $\begin{array}{l}\text { Ovine whey protein concentrate } \\
\text { (WPC) }\end{array}$ & Semi hard & $\begin{array}{l}\text { Water, glycerol, guar gum, sunflower oil, } \\
\text { tween } 20 \text {, lactic acid, natamycin }\end{array}$ & Brushing & (Henriques et al., 2013) \\
\hline \multirow[t]{2}{*}{ Whey protein isolate } & Kashar & Water, sorbitol, alginate, ginger essential oil & Dipping/immersion & (Kavas \& Kavas, 2014) \\
\hline & Lor & Water, sorbitol, mint essential oil, tween 20 & Dipping/immersion & (Kavas \& Kavas, 2014) \\
\hline Beeswax & Kashar & N/A & Dipping/immersion & (Yilmaz \& Dagdemir, 2012) \\
\hline
\end{tabular}

storage at $4^{\circ} \mathrm{C}$ through 30 days. In the uncoated cheese the microbiological acceptability limit (MAL) value (7 log CFU/g) was reached after 7 days for mesophilic bacteria, between 7 and 14 days for psychrophilic bacteria and between 14 and 21 days for lactic acid bacteria, while in coated samples, during the 30 days of evaluation, the values were always under the MAL. There was also a delay of undesirable acidity, better maintenance of texture and maintenance of sensory characteristics of the coated samples when compared to uncoated samples (Di Pierro et al., 2011). One interesting fact was the delay of lactic acid bacteria (LAB) growth in the coated cheeses, reflected on the differences in the values of maximum titratable acidity (achieved when LAB reached 5-6 log (CFU/g)). In coated cheeses the highest value was achieved after 30 days, while in control only 14 days were needed, as a consequence of the increase in production of organic acids by LAB. These examples showed that chitosan is able to display antimicrobial capacity in cheese and that can be used in combination with other natural antimicrobials, and therefore improve the overall antimicrobial properties of the coatings for application in different types of cheese.

Chitosan is without any doubt one of the most interesting candidates to formulate edible coatings for application on different types of cheese (e.g. Mozzarella, Emmental, Ricotta, semi-hard), presenting as main advantages the capacity to prevent the growth of moulds, yeasts and some bacteria such as L. monocytogenes, L. innocua, P. fluorescens and $E$. coli. Furthermore, antimicrobial properties of chitosan films can be improved using chitosan in combination with antimicrobials like natamycin and lysozyme, leading to a synergistic effect, and thus resulting in a higher antimicrobial effect. This will allow a shelf life extension in terms of microbiological load and in some cases the improvement of cheese sensory characteristics. However, it is important to mention that when using chitosan some precautions should be taken due to the acidic medium where it must be dissolved and the red-orange colour that can present. Also in some countries the use of chitosan as food additive and/or as food contact material is not allowed and thus it cannot be used as material for the production of edible coatings for food applications.

\subsection{Alginate}

Sodium alginate, normally obtained from seaweeds (Nieto, 2009), forms a strong film that when compared to other film materials like sodium caseinate and potato starch films, presents better performances regarding water permeability and mechanical properties (Wang et al., 2007). One of the most interesting properties of sodium alginate is their capacity to cross-link, when guluronic residues bind to $\mathrm{Ca}^{2+}$ ions in a process which forms an egg-box structure. This capacity allows for the development of tailor-made structures where it is possible to modify the barrier and mechanical properties of the alginate-based coatings and films.

One interesting study combined alginate-based coatings with modified atmosphere packaging (MAP) $\left(50 \%\right.$ of $\mathrm{CO}_{2}, 50 \%$ of $\left.\mathrm{N}_{2}\right)$ for the preservation of Mozzarella cheese at $4{ }^{\circ} \mathrm{C}$. The shelf life was estimated according to MAL of Pseudomonas, sensorial acceptability limit, overall quality, the average time for the latest storage time at which moulds were not visible, and earliest storage time at which moulds were visible. The cheese shelf life increased up to 160 days, while the control presented a shelf life of 53 days (Mastromatteo et al., 2014). These results 
confirm that edible coatings can also be used in combination with MAP, for the extension of cheese shelf-life.

The efficiency of alginate-based coatings can be further improved by incorporation of antimicrobials compounds. Lucera et al. (2014) evaluated the incorporation of potassium sorbate (3\%) in sodium alginatebased coating to act as an antimicrobial coating in fresh mozzarella cheese, against Enterobacteriaceae and Pseudomonas spp. The cheese samples were maintained at $8{ }^{\circ} \mathrm{C}$ during storage and the samples remained in the acceptability patterns of overall quality evaluated by sensory analysis during 8 days, while the control was refused after 4 days.

In another work, Zhong et al. (2014) used sodium alginate as a coating for low moisture Mozzarella cheese ( $9 \mathrm{~g}$ samples) and tested different methods of application (dipping, enrobing, spraying, and electrostatic spraying). The cheese hardness was used as the main quality factor, and it was observed that after 14 days at $4{ }^{\circ} \mathrm{C}$ the cheese coated with sodium alginate presented lower values of hardness $(113-135 \mathrm{~N})$ than cheese coated with chitosan and soy protein isolatebased coatings (351-522 N and 326-340 N, respectively). The capacity of sodium alginate coating to decrease moisture loss was probably the reason for the lower hardness values obtained for these cheese samples. Moreover, spraying and electrostatic spraying methods presented the best results regarding cheese hardness, when sodium alginate was used as coating.

\subsection{Whey proteins}

Whey proteins are obtained from cheese and casein manufacture and contain a diverse amount of proteins with distinctive properties. It is available as whey protein concentrate (WPC) or whey protein isolate (WPI) according to the protein content, $20-80 \%$ and $>90 \%$, respectively. They have good film forming capacity, and present as main advantages the low barrier properties, namely to oxygen (comparable to petroleum-based films), volatile aromas and lipids (Ramos et al., 2012). Ramos et al. (2012) evaluated WPI-based coatings incorporating different combinations of antimicrobial compounds to extend the shelf life of a semi-hard cheese. They observed a decrease of $10 \%$ of moisture loss and a lower variation in hardness and colour during storage for coated cheeses when compared to uncoated samples. These results showed the capacity of WPI-based coatings to act as a water vapour barrier and thus avoid water loss and guarantee hardness maintenance. Other WPI-based coatings with the incorporation of chitooligossacharides (COS) and lactic acid, were tested by Ramos et al. (2012). They applied the coating in a semi-hard cheese and observed a higher antimicrobial effect against bacteria and a lower action against yeasts and moulds when compared with a commercial coating (polyvinyl acetate with $2.5 \mathrm{~g} / \mathrm{L}$ of natamycin). In another work, it has been showed that WPI-based coatings in combination with $3 \%$ of mint essential oil in lor cheese $(50 \mathrm{~g})$ decrease the growth of microorganisms after 15 days of storage at $4{ }^{\circ} \mathrm{C}$. The cheese quality and safety was improved by a total reduction ( $0 \log \mathrm{CFU} / \mathrm{g})$ of Staphylococcus aureus, $L$. monocytogenes and yeast-mould growth and a decrease of $E$. coli (2.01 log CFU/g) growth, when compared with the control $(7.9,7.71$, 7.87 and $7.93 \log \mathrm{CFU} / \mathrm{g}$ respectively). In the same work, it was observed a complete bactericidal and antimicrobial effect when $4 \%$ of mint essential oil was used, since the first day to the end of the experiment, 15 days later, at $4{ }^{\circ} \mathrm{C}$ (Kavas \& Kavas, 2014).

\subsection{Lipids}

Lipids can be used as edible coatings (McHugh \& Krochta, 1994), however in the last years they have been mostly used in combination with other materials aiming at increasing coatings' hydrophobicity. According to their structure, they can be divided in natural waxes and resins, acetoglycerides, fatty acids, and different types of vegetable oils (Galus \& Kadzińska, 2015). They can be liquid and solid at room temperature, and this is the characteristic that will influence the way they are used; i.e. applied directly on the cheese surface or in combination with other materials in the coating formulation.

In the case of waxes, only few studies showed their potential use on cheese, being beeswax the one already applied in the cheese with success. Yilmaz and Dagdemir (2012) used beeswax in Kashar cheese in single and double layer coatings applied by immersion. The cheeses were kept ripening for 4 months at $4{ }^{\circ} \mathrm{C}$ at a relative humidity of $85 \%$, being shown that beeswax acted as a protective coating material, reducing mould to values of $1.89 \log (\mathrm{CFU} / \mathrm{g})$ at 120 th day, when compared to control that presents a value of $4.60 \mathrm{log}$ (CFU/g). Evaluating the sensorial aspects using a scale ranged from 1 (poor) to 9 (excellent) the edible coatings showed to improved texture (7.62), taste (7.61) and odour (7.62) when a single layer of beeswax coating was used and when compared with vacuum packaged Kashar cheese (7.23, 7.34 and 7.46 respectively). It was also observed a decrease of the moisture loss when comparing coated and uncoated cheese, with values of 61.36 and $67.85 \%$ of dry matter, respectively. Ünalan et al. (2013) used a zeinwax composite film in combination with lysozyme, cathechin and gallic acid acting as bioactive compounds, to coat Kashar cheese. Three different types of waxes were tested (carnauba wax, candelilla wax and beeswax) in combination with zein. When using zein-carnauba wax films, a significant reduction of $L$. monocytogenes inoculated in the cheese samples was obtained. The films with the incorporation of lysozyme, catechin and gallic acid were the ones that showed the highest antimicrobial activity with values of $5.59 \mathrm{log} \mathrm{CFU} / \mathrm{g}$ regarding $L$. monocytogenes when compared to the control (8.13 log CFU/g), and showed at the same time better antioxidant properties avoiding lipid oxidation of cheese, when stored at $4{ }^{\circ} \mathrm{C}$ for 8 weeks.

One of the strategies for the incorporation of lipids and waxes in edible coatings is through emulsion formation $(\mathrm{O} / \mathrm{W})$, where the lipid phase is mixed with other material (normally a polysaccharide or protein solution) and homogenised using mechanical shear. Ramos et al. (2012) used a mixture of sunflower oil and whey protein isolate and Cerqueira et al. (2010) used galactomannan with corn oil to form emulsified edible coatings and to incorporate a lipid in a coating. In the last case, the emulsified coating was applied in semi-hard cheese by dipping. The coated cheese presented a significant reduction of $\mathrm{O}_{2}$ consumption up to $1.30\left(\mathrm{~mL} \mathrm{~kg}^{-1} \mathrm{~h}^{-1}\right)$ and a decrease of $\mathrm{CO}_{2}$ production rate up to $1.5\left(\mathrm{~mL} \mathrm{~kg}^{-1} \mathrm{~h}^{-1}\right)$ after storage at $20^{\circ} \mathrm{C}$ when compared with the uncoated cheese. Also, a reduction of weight loss $3.8 \%$ and $3.1 \%$ - was observed when compared with uncoated cheese, for a storage temperature of $4{ }^{\circ} \mathrm{C}$ and $20^{\circ} \mathrm{C}$, respectively. The use of emulsified edible coatings is an interesting strategy to have an edible coating easy to apply while presenting at the same time a hydrophobic portion. This can be used to enhance and control the barrier properties of the coatings using different formulations (i.e. different amounts of lipids and waxes can be used) and therefore decrease the water loss of cheeses during storage.

\section{Antimicrobials for use in coatings}

The use of antimicrobials is one of the possibilities to decrease the growth of bacteria, moulds and yeasts in cheese. Normally, they are added during cheese production or in the cheese surface in their free form. When directly applied (i.e. free form) on cheese surface these antimicrobials can be affected by a partial inactivation of the active substance (Reps, Drychowski, Tomasik, \& Wiñnieswska, 2002) and an undesired rapid diffusion within the food bulk (Ouattara, Simard, Piett, Bégin, \& Holley, 2000). This problem can be partially solved by their incorporation in the coating matrix resulting in a reduction of the cheese spoilage through the protection of cheese surface against microbial contamination, since edible coatings have the capacity to maintain high concentrations of the active substance on the cheese surface preventing its migration and thereby the critical concentration is sustained for an extended period of time and the application 
Table 2

Antimicrobials used in coatings for cheese application.

\begin{tabular}{|c|c|c|c|}
\hline Antimicrobial & Concentration & Effect against & References \\
\hline Citric acid & $6 \mathrm{~g} / \mathrm{L}$ & $\begin{array}{l}\text { Escherichia coli } \\
\text { Listeria innocua } \\
\text { Yarrowia lipolytica }\end{array}$ & (Ramos et al., 2012) \\
\hline Lactic acid & $6 \mathrm{~g} / \mathrm{L}$ & $\begin{array}{l}\text { Staphylococcus spp. } \\
\text { Pseudomonas spp. } \\
\text { Enterobacteriaceae } \\
\text { Yeasts } \\
\text { Moulds }\end{array}$ & (Henriques et al., 2013) \\
\hline Malic acid & $30 \mathrm{~g} / \mathrm{L}$ & Listeria monocytogenes & (Pintado, Ferreira, \& Sousa, 2010) \\
\hline Oregano essential oil (EO) & $20 \mathrm{~g} / \mathrm{kg}$ & Staphylococcus aureus & (Artiga-Artigas et al., 2017) \\
\hline Olive leaf extract & $15 \mathrm{~g} / \mathrm{L}$ & & (Ayana \& Turhan, 2009) \\
\hline Ginger EO & $15 \mathrm{~g} / \mathrm{L}$ & & (Kavas, Kavas, \& Saygili, 2016) \\
\hline Lemon extract & $>0.5 \mathrm{~g} / \mathrm{L}$ & Pseudomonas spp. & (Conte, Scrocco, Sinigaglia, \& Del Nobile, 2007) \\
\hline Garlic EO & $>30 \mathrm{~g} / \mathrm{L}$ & $\begin{array}{l}\text { Escherichia coli } \\
\text { Listeria monocytogenes } \\
\text { Salmonella enteridis } \\
\text { Lactobacillus plantarum }\end{array}$ & (Seydim \& Sarikus, 2006) \\
\hline $\begin{array}{l}\text { Rosemary EO } \\
\text { Oregano EO }\end{array}$ & $330 \mathrm{~mL} / \mathrm{L}$ & $\begin{array}{l}\text { Mucor } \\
\text { Penicillium }\end{array}$ & (Embuena et al., 2016) \\
\hline \multirow[t]{3}{*}{ Lysozyme } & $18 \mathrm{~g} / \mathrm{L}$ & $\begin{array}{l}\text { Pseudomonas fluorescens } \\
\text { Escherichia coli }\end{array}$ & (Duan et al., 2007) \\
\hline & $11.7 \mathrm{~g} / \mathrm{kg}$ of film forming solution (FS) & Listeria monocytogenes & (Ünalan et al., 2013) \\
\hline & $0.25 \mathrm{~g} / \mathrm{L}$ & $\begin{array}{l}\text { Pseudomonas spp. } \\
\text { Coliforms }\end{array}$ & (Conte, Gammariello, Di Giulio, Attanasio, \& Del Nobile, 2009) \\
\hline \multirow[t]{2}{*}{ Natamycin } & $\begin{array}{l}0.07 \mathrm{~g} / \mathrm{kg} \\
>0.2 \mathrm{~g} / \mathrm{kg} \text { FS } \\
>0.2 \mathrm{~g} / \mathrm{L} \\
>20 \mathrm{~g} / \mathrm{kg} \text { cellulose } \\
0.27 \mathrm{~g} / \mathrm{kg}\end{array}$ & $\begin{array}{l}\text { Moulds } \\
\text { Aspergillus niger } \\
\text { Candida albicans } \\
\text { Penicillium roquefortii } \\
\text { Yarowia lipolytica } \\
\text { Sacharomyces cerevisiae } \\
\text { Zygosaccharomyces rouxii }\end{array}$ & $\begin{array}{l}\text { (Yangılar \& Oğuzhan Yildız, 2015) } \\
\text { (Ture, Eroglu, Ozen, \& Soyer, 2011) } \\
\text { (Romero, Borneo, Passalacqua, \& Aguirre, 2016) } \\
\text { (Oliveira, Soares, Pereira, \& Fraga, 2007) } \\
\text { (Ollé Resa et al., 2014) }\end{array}$ \\
\hline & $>2 \mathrm{~g} / \mathrm{L}$ & $\begin{array}{l}\text { Penicillium commune } \\
\text { Penicillium chrysogenum }\end{array}$ & (Pintado et al., 2010) \\
\hline Nisin & $0.05 \mathrm{~g} / \mathrm{kg}$ & Listeria monocytogenes & (Fajardo et al., 2010) \\
\hline Potassium sorbate & $1 \mathrm{~g} / \mathrm{L}$ & $\begin{array}{l}\text { Enterobacteriaceae } \\
\text { Pseudomonas spp. }\end{array}$ & (Mastromatteo et al., 2014) \\
\hline
\end{tabular}

efficiency increased (Fajardo et al., 2010). There are several compounds that can be used as antimicrobial with different purposes; i.e. against bacteria, moulds or yeasts, and that are approved for food applications (Moreira et al., 2011; Ollé Resa et al., 2014). Some of the tested antimicrobials together with edible coatings materials used are presented in Table 2.

\subsection{Nisin}

Concerning antimicrobials and their field of action, the bacteriocin nisin is used as a food preserving agent, namely in the dairy industry, against the Gram-positive bacteria (Delves-Broughton, 1990; DelvesBroughton \& Thomas, 2005). Due to this, nisin was used in several edible coatings showing effects on the microbial growth delay of several types of cheese. For Ricotta cheese, after 7 days at $4{ }^{\circ} \mathrm{C}$ the count of inoculated $L$. monocytogenes in the cheese surface was lower $(\approx 4 \log$ $\mathrm{CFU} / \mathrm{g})$ than in samples without coating $(p<0.05)(\approx 6.2 \log \mathrm{CFU} / \mathrm{g})$ and lower, than in samples with galactomannan-based coating without nisin ( $\approx 4.7 \log \mathrm{CFU} / \mathrm{g}$ ), showing that the presence of a coating with the addition of nisin can be used to reduce the growth of $L$. monocytogenes (Martins et al., 2010). In other work, WPI-based films with 3\% malic acid and $50 \mathrm{IU} / \mathrm{mL}$ of nisin was used against $P$. aeruginosa and $L$. monocytogenes isolated from Castelo Branco cheese. It was observed an inhibition zone of $3.2 \mathrm{~mm}$ for $L$. monocytogenes, and $0.8 \mathrm{~mm}$ for $P$. aeruginosa showing the antimicrobial activity of nisin and malic acid against these bacteria (Pintado et al., 2010). Cui et al. (2016) applied chitosan-based coatings with nisin-silica liposomes on fresh Cheddar cheese samples $(30 \times 25 \times 10 \mathrm{~mm})$ and besides the antibacterial activity against $L$. monocytogenes observed at $25^{\circ} \mathrm{C}$ for 7 days $(8.04 \mathrm{log}$ $\mathrm{CFU} / \mathrm{g}$ in control and $5.48 \log \mathrm{CFU} / \mathrm{g}$ in nisin-silica liposomes) and at
$4{ }^{\circ} \mathrm{C}$ for 15 days (4.88 $\log \mathrm{CFU} / \mathrm{g}$ in control and $4.48 \log \mathrm{CFU} / \mathrm{g}$ in nisinsilica liposomes), they showed that sensorial characteristics (colour, taste, texture and off-flavour), using a 9-point hedonic scale, remained the same $(\approx 4.61-5.18)$ during the evaluation period. The maintenance of the cheese sensory characteristics was observed when compared with the control samples, both a fresh cheese and a cheese stored during 15 days at $4{ }^{\circ} \mathrm{C}$.

\subsection{Natamycin}

Natamycin (also known commercially as pimaricin) belongs to polyene antibiotics. It is produced by submerged aerobic fermentation of Streptomyces natalensis and related species. It is used as antimicrobial on the surface of cheeses due to its activity against yeasts and moulds. Although it was proved that natamycin has no toxic effects even at high levels of ingestion, its application as food additive is still restricted by law all around the world. The objective is to avoid its migration to the internal part of the foods, because of the possible danger of the occurrence of antibiotic resistance. Companies use natamycin in a very wide range of concentrations from 500 to $10,000 \mathrm{ppm}$ when the legal concentration defined by the FDA (USA) and Canadian authorities is $20 \mathrm{ppm}$ while in Europe it is $1 \mathrm{mg} / \mathrm{dm}^{2}$ for cheese surface (not present at a depth of $5 \mathrm{~mm}$ ) (European Parliament and Council, 2011). One of the problems with the use of natamycin is the fact that $50 \%$ of the commercial product is lactose, leading to precipitation and difficulty of dispersing this commercial natamycin product in foods. Because of this, recently, some companies sell natamycin with high stability in solution.

Also edible coatings have been used as a carrier of natamycin for applications on cheese. One of the examples was presented by Ture et al. (2011) that used wheat gluten-based coatings with natamycin to 
decrease the microbiological growth on fresh cheese during storage. They showed an effective elimination of $A$. niger in fresh Kashar cheese surface after 30 days of storage at $10{ }^{\circ} \mathrm{C}$ when $2 \mathrm{mg}$ of natamycin was used per $10 \mathrm{~g}$ of film solution. For polysaccharide-based coatings there are more examples showing the capacity of polysaccharide coatings to act as a carrier of natamycin. Tapioca starch-based coatings with $0.027 \mathrm{~g}$ of natamycin per $100 \mathrm{~g}$ of film solution (Ollé Resa et al., 2014) were tested in $5 \mathrm{~g}$ of Port Salut cheese $(2.5 \times 2.5 \times 0.5 \mathrm{~cm})$ inoculated with $20 \mu \mathrm{L}$ of a mixed culture of Saccharomyces cerevisiae and Listeria. innocua. $\left(10^{6} \mathrm{CFU} / \mathrm{mL}\right)$ and showed to be effective in the prevention of external contamination by $S$. cerevisiae after 5 days at $25^{\circ} \mathrm{C}$ while for $\mathrm{L}$. innocua just delayed the growth, since after $48 \mathrm{~h}$ occurred the bacteria growth. Cellulose-based coatings with $2 \%$ and $4 \%$ of natamycin (Oliveira et al., 2007) showed efficiency in growth inhibition of Penicillium roqueforti in Gorgonzola cheese. Results showed that the amount of natamycin released to the cheese was below the limit $(1.67 \mathrm{mg} / \mathrm{kg}$ for $2 \%$ of natamycin and $1.99 \mathrm{mg} / \mathrm{kg}$ for $4 \%$ of natamycin) allowed by the Brazilian legislation ( $5 \mathrm{mg} / \mathrm{kg}$ not detectable at $2 \mathrm{~mm}$ depth) after 45 days of ripening.

\subsection{Lysozyme}

Lysozyme is a lytic enzyme found in many natural systems, and has been used in edible coatings to prevent the growth of Gram-positive bacteria on cheese. Lysozyme attacks the $\beta-1-4$ glycosidic linkage between the $N$-acetylmuramic acid and $N$-acetylglucosamine groups (Conte et al., 2007). Conte et al. (2009) used a combination of sodium alginate coating with lysozyme and MAP conditions $\left(30 \% \mathrm{CO}_{2}, 5 \% \mathrm{O}_{2}\right.$, and $65 \% \mathrm{~N}_{2}$ ) in Fior di latte cheese $(50 \mathrm{~g})$ and evaluate the shelf life extension using the lowest value between MAL and sensorial acceptability value at $10^{\circ} \mathrm{C}$. They observed a shelf life increase of 3 days when compared to control. Also, when evaluating sensorial properties related to external appearance, consistency, colour, flavour and overall acceptability using a scale from 0 to 7 where 4 was selected as the threshold of acceptability, the values of sensorial acceptability of the cheese were the same comparing the coated cheese with the control, being 3 days of storage the maximum acceptable. Probably these results can be related to the fact that there was a removal of the coating and a washing process in water for $10 \mathrm{~min}$ of the cheese before the evaluation of the participants. Ünalan et al. (2013) used it in Kashar cheese slices (0.7 mm thickness) and Duan et al. (2007) did the same in mozzarella cheese and proved that coatings with lysozyme exert an antimicrobial effect extending the cheese shelf life. In Ünalan et al. (2013) work, the use of lysozyme avoided $L$. monocytogenes growth (remained between 5.5 and $6 \log \mathrm{CFU} / \mathrm{g}$ ) through 8 weeks at $4{ }^{\circ} \mathrm{C}$ while in uncoated cheese the growth was from 5.5 to $8 \log \mathrm{CFU} / \mathrm{g}$. Duan et al. (2007) showed the antimicrobial effect of chitosan coating with $60 \%$ of lysozyme and an adjusted $\mathrm{pH}$ of 5.2 , by the inoculation of $L$. monocytogenes in the mozzarella cheese samples $(10 \mathrm{~g})$ stored at $10^{\circ} \mathrm{C}$ during 14 days. The contamination by L. monocytogenes was reduced at the end of 14 days of storage presenting values of approximately $3 \log \mathrm{CFU} / \mathrm{g}$ while in the uncoated cheese the contamination values of $L$. monocytogenes remained the same during the 14 days of storage (4.48 to $4.32 \log$ CFU/ g). Although an antimicrobial effect was observed, the efficiency of the chitosan coating with lysozyme was very low. In this case, other chitosan-based coating formulations could be tested, where a higher concentration of lysozyme or the combination with other antimicrobials could be used to increase the antimicrobial effect.

\subsection{Essential oils}

Essential oils from various plant species have proven to inhibit microbial growth and at the same time good antioxidant properties, being good candidates for cheese preservation. They possess a broad spectrum against different pathogenic and spoilage microorganisms. They have the advantage of having the GRAS (Generally Recognized As
Safe) status and being approved for use in EU (European Parliament and Council, 2008). Essential oils like linalool, carvacrol and thymol were incorporated by Kuorwel, Cran, Sonneveld, Miltz, and Bigger (2013) in a starch-based coating and then applied on Cheddar cheese surface showing antifungal activity against Aspergillus niger. The coating containing thymol at $2.38 \%$ showed the highest decrease in the microbiological growth $(\approx 2.55 \log \mathrm{CFU} / \mathrm{g})$ after 35 days of storage at $15^{\circ} \mathrm{C}$ while in the coating without essential oils, the decrease was lower (4.25 log CFU/g) during the same period when compared to control $(\approx 4.75 \log \mathrm{CFU} / \mathrm{g}$ ). Other essential oil (i.e. oregano essential oil (OEO)) was incorporated in nanoemulsions with sodium alginate, Tween 80 and mandarin fiber and then tested in low-fat cut cheese $(10 \mathrm{~g})$. The use of a concentration of $2.0 \%$ of OEO reduced the growth of $S$. aureus down to $4.6 \log (\mathrm{CFU} / \mathrm{g})$ when compared with control $(6 \log \mathrm{CFU} / \mathrm{g})$ after 15 days of storage at $4{ }^{\circ} \mathrm{C}$. The use of concentrations of $2.5 \%$ of OEO also inhibited psychrophilic bacteria during 6 days and moulds and yeasts during 24 days of storage (Artiga-Artigas et al., 2017).

Nevertheless, and despite showing a good potential as antimicrobials, the use of essential oils is restricted due to their effect on organoleptic properties of cheese once their high odour and flavouring at high concentrations can change cheese's flavour. One of these examples was presented by Yangilar (2016) that tested the incorporation of a fish essential oil (1\%) in chitosan-based coatings aiming to extend the shelf-life of Göbek Kashar Cheese. Although a decrease in moulds growth occurred when using chitosan-based coating with fish oil (1.15 log CFU/g) compared to control (3.89 $\log \mathrm{CFU} / \mathrm{g}$ ) after 90 days of ripening, the sensorial evaluation of coated cheese received the lowest scores. The use of essential oils can be a good option in order to increase the quality and safety of cheese, however the sensorial evaluation should always be taken into account when considering their industrial applications.

\subsection{Organic acids}

Organic acids are usually used as food additives for food preservation due to their antimicrobial activity and acidifying capacity (Henriques et al., 2013; Pintado et al., 2010). The reason for these antimicrobial activities is related to the organic acids chelating activity and ability to dissociate inside the cell and decrease $\mathrm{pH}$. Organic acids activity is also related to $\mathrm{p} K_{a}$ since lower values of $\mathrm{p} K_{a}$ lead to a higher decrease of $\mathrm{pH}$. Some works also showed the synergy between organic acids and other antimicrobials such as natamycin and nisin (Pintado, Ferreira, \& Sousa, 2009). In the case of nisin this behaviour is explained by its effect on bacteria membrane, opening pores that allow an easier penetration of the organic acids (Pintado et al., 2009) and thus an improved antimicrobial activity. One example was reported by Pintado et al. (2009), using WPI-based coatings combining citric, lactic and malic acid together with nisin. Results showed that the organic acids have on their own an anti-listeria effect that in combination with nisin, is increased, revealing a synergistic effect. WPI-based coatings with malic and citric acid exhibited the greatest inhibitory effect against $L$. monocytogenes and L. innocua strains revealing the antimicrobial potential of organic acids. Also Ramos, Pereira et al. (2012b) used 6 g/L of lactic acid combined with chitoligossacharides and natamycin in WPIbased coatings. This combination decreased the growth $(<100 \log$ CFU/g) of Staphylococcus spp., Pseudomonas spp., Enterobacteriaceae, yeasts and moulds ensuring cheese quality for at least 60 days of storage.

Henriques et al. (2013) used malic acid in combination with natamycin and nisin in WPC coating, and tested different polymerization methods: heat denaturation (HD), UV polymerization (UV) and both methods combined (HD + UV). From the results, it was concluded that the best antimicrobial performance was achieved using WPC coating with HD + UV polymerization. This coating prevents the growth of Enterobacteriaceae, yeasts and moulds (CFU counts remained constant) and leads to the microbial inhibition of Staphylococcus spp. Those 
results showed that the antimicrobial activity was enhanced by the protein polymerization (both HD and UV), showing that using these methods it is possible to improve WPC-based coatings performance.

Other of the possibilities is to join MAP and antimicrobial compounds to extend cheese shelf-life. Mastromatteo et al. (2014) used potassium sorbate in a sodium alginate-based coating to coat mozzarella cheese and showed that in combination with MAP it was able to improve cheese preservation and the extension of cheese shelf life. They showed that the presence of potassium sorbate in alginate-based coatings increases shelf life of mozzarella from 53 days to 108 days at $4{ }^{\circ} \mathrm{C}$ and from 108 to 166 days when MAP is used with $50 \%$ of $\mathrm{CO}_{2}$ and $50 \%$ of $\mathrm{N}_{2}$. Also the mozzarella samples were subjected to sensory analysis by 7 evaluators, being colour, odour, taste and firmness evaluated using a scale ranged from 1 to 7 . The samples overall quality was considered as the average of the four attributes (colour, odour, taste and firmness), the minimum threshold was the score of 4 . The results showed that the control cheese reached the minimum threshold faster than the coated samples. Also all the sensorial attributes compromised the overall quality of the control cheese, while for the coated samples the loss of quality was mainly due to the texture. Moreover, for the control the sensorial acceptability limit was 53 days, while for coated samples the limit value was 100 days for coated samples and 166 days for coated samples in combination with MAP.

\section{Application methods of edible coatings and films on cheese}

One of the important aspects of the use of coatings is the application method, once the choice will depend on the type and size of the cheese where the coating is going to be applied. This choice will affect the cost and the efficiency of the coating and should be adapted to the production process (at the end of production, before or after the maturation step). The application of an edible packaging (coatings or films) can be performed by dipping, spraying, electrostatic spraying and brushing in the case of coatings and individual wrapping in the case of films (Ollé Resa et al., 2012; Zhong et al., 2014). The most suitable application method will be the one that guarantees the total covering of the cheese and thus contributes to a better extension of the shelf life. It is also important to consider the type of cheese and the scale of the production process where it will be applied, once their specifications will define the application method to be used (e.g. in an industry of small dimension the brushing method can be used in order to avoid the use of huge tanks for dipping or expensive machines for spraying; the opposite would be the case for large industrial facilities).

Factors like irregular surface, costs and simplicity make dipping the method of choice in the cheese industry, once it allows covering all the surface by immersion being the excess removed through draining or using a dryer (Mastromatteo et al., 2015; Yangılar \& Oğuzhan Y1ldız, 2015). On the other hand if the objective is to obtain a thinner and uniform coating, spraying is more effective (Zhong et al., 2014). The efficiency of the process can be increased if electrostatic spraying is used. This methodology is being adapted to the food industry and allows high efficiencies avoiding coating wastage, which is the major drawback of the dipping method (Barringer \& Sumonsiri, 2015; Zhong et al., 2014).

Wrapping is another way to use edible packaging to extend cheese shelf-life. In this case, films (produced previously to application) are used to cover the cheese surface by wrapping it. Studies were already performed and showed that films are able to suppress bacteria and moulds and to be an effective packaging material (Duan et al., 2007; Moreira et al., 2011; Ture et al., 2011).

The development, adjustment or improvement of packaging methods is being done (e.g. electrostatic coating) and brings optimization and benefits unseen before in packaging and in food quality. New approaches should be tested in order to innovate and develop even better methodologies to increase the efficiency of edible coatings and films. New methods to apply coatings such as electrospray and vibrational atomization can be seen as new approaches to improve coating efficiency.

\section{Commercial applications and future trends}

In the current market, there are already some companies exploring edible coatings and films for cheese. Having in mind their potential and the way they can be used to extend the cheese shelf-life, these companies are developing tailored made coatings and films for different types of cheese. Improveat (Braga, Portugal) produces several bio-based coatings, BecorBarbanza (A Coruña, Spain) presents in their portfolio several types of coatings including edible coatings for cheeses and Vink chemicals GmbH \& Co (Kakenstorf, Germany) has several coatings among which there are natural coatings for cheese. Also, some patents have been submitted showing the interest and potential use of this technology and its commercial value. Some of the patents submitted in the last ten years are related to cheese coating composition (EP 1642504 A1, EP 1980162 A1, EP 2443934 A1), RU2520079 (C2)), novel coating systems (WO 2013053793 A1) and methods for providing a coated cheese (EP2272376 A1). The fact that companies from different countries are already commercializing this technology is a sign that edible coatings and films are a promise to extend cheese shelf-life, and that they should be more exploited in order to become a reality available for all types of cheese.

The use of edible coatings and films in the food industry, mainly in cheeses, still presents some challenges. The main challenges are: i) their effect on the colour and flavour of cheese which can be unattractive for consumers (not all coatings and films have this drawback, but some do), ii) the difficulty to obtain an homogenous covering of the food surface, iii) the need for a higher amount of natural active compounds for the development of effective active coatings and films when compared with non-natural ones, and iv) the price of some of the materials used that increases the cost of application of this kind of technology in cheese industry.

These issues are some of the issues identified in the last years and which may be overcome based on new and emerging technologies. One of the possibilities is the use of nanotechnology, where the control of materials properties at nanosize scale will allow exploring new functionalities. Some of the advantages of using nanotechnology in the food industry have been extensively reviewed (Cerqueira, Costa, Rivera, Ramos, \& Vicente, 2014; Ghorani \& Tucker, 2015; Livney, 2015; O'Callaghan \& Kerry, 2016) being the most interesting for edible coatings and films their capacity to improve solubility of compounds, mask flavours, protect functional compounds against chemical degradation and controlled release of active compounds. In fact, the use of nanostructured systems for the encapsulation of active compounds is already known in edible coatings and films, and several authors showed the possibility of using nanoparticles or active-loaded nanostructures to improve their performance (Fuciños et al., 2017; Zambrano-Zaragoza et al., 2013). Also the use of nano-coatings has been proposed as a way to apply edible coatings to foods (Zambrano-Zaragoza et al., 2014) and their application to cheese has been recently demonstrated (Medeiros et al., 2013). Nevertheless, the use of nanotechnology in food products should be evaluated carefully due to safety reasons (i.e. the use of nanomaterials in foods should be tested (EFSA Scientific Committee, 2011)) and their use in edible coatings and films for cheese applications should be further explored.

\section{Conclusion}

Due to their edibility, edible coatings and films are a promising investment as an alternative to non-edible coatings and films, since they allow as well as non-edible coatings and films the reduction of weight loss, control of respiratory rate and the prevention of spoilage, and thus can have be an important and sustainable alternative in the preservation of cheese quality and safety. Their use for cheese preservation is 
becoming more exploited and resulted in the commercialization of edible coatings and films by some companies, demonstrating their potential as alternatives to the existing petroleum-based coatings that are used in cheese surface protection. In the last 10 years, edible coatings and films for cheese became a reality, moving from the scientific research for commercial applications, which are likely to have a continuous growth in the future with the use of new and emerging technologies, e.g. nanotechnology.

\section{Acknowledgments}

This study was supported by the Portuguese Foundation for Science and Technology (FCT) under the scope of the strategic funding of UID/ BIO/04469/2013 unit and COMPETE 2020 (POCI-01-0145-FEDER006684) and BioTecNorte operation (NORTE-01-0145-FEDER-000004) funded by the European Regional Development Fund under the scope of Norte2020 - Programa Operacional Regional do Norte. Maria José Costa is recipient of a fellowship supported by a doctoral program (SFRH/BD/122897/2016) funded by the Portuguese Foundation for Science and Technology (FCT, POPH-QREN and FSE Portugal).

\section{References}

Al-Hassan, A. A., \& Norziah, M. H. (2012). Starch-gelatin edible films: Water vapor permeability and mechanical properties as affected by plasticizers. Food Hydrocolloids, 26(1), 108-117.

Artiga-Artigas, M., Acevedo-Fani, A., \& Martín-Belloso, O. (2017). Improving the shelf life of low-fat cut cheese using nanoemulsion-based edible coatings containing oregano essential oil and mandarin fiber. Food Control, 76, 1-12.

Ayana, B. B., \& Turhan, K. N. (2009). Use of Antimicrobial Methylcellulose Films to Control Staphylococcus aureus During Storage of Kasar Cheese and Science. Packaging Technology and Science, 22, 461-469.

Balaguer, M. P., Fajardo, P., Gartner, H., Gomez-Estaca, J., Gavara, R., Almenar, E., \& Hernandez-Munoz, P. (2014). Functional properties and antifungal activity of films based on gliadins containing cinnamaldehyde and natamycin. International Journal of Food Microbiology, 173, 62-71.

Barringer, S. A., \& Sumonsiri, N. (2015). Electrostatic coating technologies for food processing. Annual Review of Food Science and Technology, 6, 157-169.

Bourbon, A. I., Pinheiro, A. C., Cerqueira, M. A., Rocha, C. M. R., Avides, M. C., Quintas, M. A. C., \& Vicente, A. A. (2011). Physico-chemical characterization of chitosanbased edible films incorporating bioactive compounds of different molecular weight. Journal of Food Engineering, 106(2), 111-118.

Cerqueira, M. A., Costa, M. J., Rivera, M. C., Ramos, Ó. L., \& Vicente, A. A. (2014). Flavouring and coating technologies for preservation and processing of foods. In S. Bhattacharya (Ed.). Conventional and advanced food processing technologies (pp. 267312). (First edit). UK: John Wiley \& Sons, Ltd.

Cerqueira, M. A., Lima, A. M., Souza, B. W. S., Teixeira, J. A., Moreira, R. A., \& Vicente, A. A. (2009). Functional polysaccharides as edible coatings for cheese. Journal of Agricultural and Food Chemistry, 57(4), 1456-1462.

Cerqueira, M. A., Sousa-Gallagher, M. J., Macedo, I., Rodriguez-Aguilera, R., Souza, B. W. S., Teixeira, J. A., \& Vicente, A. A. (2010). Use of galactomannan edible coating application and storage temperature for prolonging shelf-life of "regional" cheese. Journal of Food Engineering, 97(1), 87-94.

Cerqueira, M. A., Souza, B. W. S., Teixeira, J. A., \& Vicente, A. A. (2012). Effect of glycerol and corn oil on physicochemical properties of polysaccharide films - A comparative study. Food Hydrocolloids, 27(1), 175-184.

Coma, V., Martial-Gros, A., Garreau, S., Copinet, A., Salin, F., \& Deschamps, A. (2002). Edible antimicrobial films based on chitosan matrix. Food Microbiology and Safety, 67(3), 1162-1169.

Conte, A., Gammariello, D., Di Giulio, S., Attanasio, M., \& Del Nobile, M. A. (2009). Active coating and modified-atmosphere packaging to extend the shelf life of Fior di Latte cheese. Journal of Dairy Science, 92(3), 887-894.

Conte, A., Scrocco, C., Sinigaglia, M., \& Del Nobile, M. A. (2007). Innovative active packaging systems to prolong the shelf life of mozzarella cheese. Journal of Dairy Science, 90(5), 2126-2131.

Cui, H. Y., Wu, J., Li, C. Z., \& Lin, L. (2016). Anti-listeria effects of chitosan-coated nisinsilica liposome on cheddar cheese. Journal of Dairy Science, 99(11), 8598-8606.

Delves-Broughton, J. (1990). Nisin and its application as a food preservative. International Journal of Dairy Technology, 43(3), 73-76.

Delves-Broughton, J., \& Thomas, L. (2005). Nisin. In J. N. S. A. L. B. P, \& M. Davidson (Eds.). Antimicrobials in food (pp. 237-274). CRC Press.

Di Pierro, P., Sorrentino, A., Mariniello, L., Giosafatto, C. V. L., \& Porta, R. (2011). Chitosan/whey protein film as active coating to extend ricotta cheese shelf-life. LWT Food Science and Technology, 44(10), 2324-2327.

Duan, J., Park, S.-I., Daeschel, M. A., \& Zhao, Y. (2007). Antimicrobial chitosan-lysozyme (CL) films and coatings for enhancing microbial safety of mozzarella cheese. Journal of Food Science, 72(9) (M355-62).

Embuena, A. I., Nácher, M., Boix, A., Pons, M. P., Llopis, M., Martínez, M. C., \& Martínez, C. (2016). Quality of goat's milk cheese as affected by coating with edible chitosan- essential oil films. International Journal of Dairy Technology, 70(1).

Fadini, A. L., Rocha, F. S., Alvim, I. D., Sadahira, M. S., Queiroz, M. B., Alves, R. M. V., \& Silva, L. B. (2013). Mechanical properties and water vapour permeability of hydrolysed collagen-cocoa butter edible films plasticised with sucrose. Food Hydrocolloids, 30(2), 625-631.

Fajardo, P., Martins, J. T., Fuciños, C., Pastrana, L., Teixeira, J. A., \& Vicente, A. A. (2010). Evaluation of a chitosan-based edible film as carrier of natamycin to improve the storability of Saloio cheese. Journal of Food Engineering, 101(4), 349-356.

Fuciños, C., Amado, I. R., Fuciños, P., Fajardo, P., Rúa, M. L., \& Pastrana, L. M. (2017). Evaluation of antimicrobial effectiveness of pimaricin-loaded thermosensitive nanohydrogel coating on Arzúa-Ulloa DOP cheeses. Food Control, 73, 1095-1104.

Galus, S., \& Kadzińska, J. (2015). Food applications of emulsion-based edible films and coatings. Trends in Food Science \& Technology, 45(2), 273-283.

Garcia, E., \& Barret, D. M. (2002). Preservative treatments for fresh-cut fruits and vegetables. In O. Lamikanra (Ed.). Fresh-cut fruits and vegetables science (pp. 267-304). Boca Raton: CRC Press.

Ghorani, B., \& Tucker, N. (2015). Fundamentals of electrospinning as a novel delivery vehicle for bioactive compounds in food nanotechnology. Food Hydrocolloids, 51, 227-240.

Henriques, M., Santos, G., Rodrigues, A., Gomes, D., Pereira, C., \& Gil, M. (2013). Replacement of conventional cheese coatings by natural whey protein edible coatings with antimicrobial activity. Journal of Hygienic Engineering and Design, 3, 34-47.

Kampf, N., \& Nussinovitch, A. (2000). Hydrocolloid coating of cheeses. Food Hydrocolloids, 14, 531-537.

Kavas, G., \& Kavas, N. (2014). The effects of mint (Mentha spicata) essential oil fortified edible films on the physical, chemical and microbiological characteristics of lor cheese. Journal of Food, Agriculture and Environment, 12(3-4), 40-45.

Kavas, N., Kavas, G., \& Saygili, D. (2016). Use of ginger essential oil-fortified edible coatings in Kashar cheese and its effects on Escherichia coli O157:H7 and Staphylococcus aureus. CyTA - Journal of Food, 14(2), 317-323.

Kuorwel, K. K., Cran, M. J., Sonneveld, K., Miltz, J., \& Bigger, S. W. (2013). Migration of antimicrobial agents from starch-based films into a food simulant. LWT - Food Science and Technology, 50(2), 432-438.

Livney, Y. D. (2015). Nanostructured delivery systems in food: Latest developments and potential future directions. Current Opinion in Food Science, 3, 125-135.

Lucera, A., Mastromatteo, M., Conte, A., Zambrini, A. V., Faccia, M., \& Del Nobile, M. A. (2014). Effect of active coating on microbiological and sensory properties of fresh mozzarella cheese. Food Packaging and Shelf Life, 1(1), 25-29.

Mannheim, C. H., \& Soffer, T. (1996). Shelf-life extension of cottage cheese by modified atmosphere packaging. LWT - Food Science and Technology, 29(8), 767-771.

Martins, J. T., Cerqueira, M. A., Souza, B. W. S., Avides, M. C., \& Vicente, A. A. (2010) Shelf-life extension of Ricotta cheese using coatings of galactomannans from nonconventional sources incorporating nisin against Listeria monocytogenes. Journal of Agricultural and Food Chemistry, 58, 1884-1891.

Martins, J. T., Cerqueira, M. A., \& Vicente, A. A. (2012). Influence of $\alpha$-tocopherol on physicochemical properties of chitosan-based films. Food Hydrocolloids, 27(1), 220-227.

Mastromatteo, M., Conte, A., Faccia, M., Del Nobile, M. A., \& Zambrini, A. V. (2014) Combined effect of active coating and modified atmosphere packaging on prolonging the shelf life of low-moisture mozzarella cheese. Journal of Dairy Science, 97(1), $36-45$.

Mastromatteo, M., Conte, A., Lucera, A., Saccotelli, M. A., Buonocore, G. G., Zambrini, A. V., \& Del Nobile, M. A. (2015). Packaging solutions to prolong the shelf life of Fiordilatte cheese: Bio-based nanocomposite coating and modified atmosphere packaging. LWT - Food Science and Technology, 60(1), 230-237.

McHugh, T. H., \& Krochta, J. M. (1994). Water vapor permeability properties of edible whey protein-lipid emulsion films. Journal of the American Oil Chemists' Society, 71, 307-312.

McSweeney, P. L. H., Ottogalli, G., \& Fox, P. F. (2004). Major cheese groups. Cheese: Chemistry, physics and microbiology. Vol. 2Elsevier.

Medeiros, B. G. S., Souza, M. P., Pinheiro, A. C., Bourbon, A. I., Cerqueira, M. A., Vicente, A. A., \& Carneiro-da-Cunha, M. G. (2013). Physical characterisation of an alginate/ lysozyme nano-laminate coating and its evaluation on "Coalho" cheese shelf life. Food and Bioprocess Technology, 7(4), 1088-1098.

Moreira, M. R., Pereda, M., Marcovich, N. E., \& Roura, S. I. (2011). Antimicrobial effectiveness of bioactive packaging materials from edible chitosan and casein polymers: Assessment on carrot, cheese, and salami. Journal of Food Science, 76(1), M54-M63.

Nieto, M. B. (2009). Structure and Function of Polysaccharide Gum-Based Edible Films and Coatings. In K. Huber, \& M. Embuscado (Eds.). Edible Films and Coatings for Food Applications (pp. 57-112). New York: E. Springer.

O'Callaghan, K. A. M., \& Kerry, J. P. (2016). Consumer attitudes towards the application of smart packaging technologies to cheese products. Food Packaging and Shelf Life, 9, 1-9.

Oliveira, T., Soares, N., Pereira, R., \& Fraga, K. (2007). Development and evaluation of antimicrobial natamycin-incorporated film in gorgonzola cheese conservation. Packaging Technology and Science, 20, 147-153.

Ollé Resa, C. P., Gerschenson, L. N., \& Jagus, R. J. (2012). Effect of natamycin on physical properties of starch edible films and their effect on Saccharomyces cerevisiae activity. Food and Bioprocess Technology, 6(11), 3124-3133.

Ollé Resa, C. P., Jagus, R. J., \& Gerschenson, L. N. (2014). Effect of natamycin, nisin and glycerol on the physicochemical properties, roughness and hydrophobicity of tapioca starch edible films. Materials Science \& Engineering. C, Materials for Biological Applications, 40, 281-287.

Ouattara, B., Simard, R. E., Piett, G., Bégin, A., \& Holley, R. A. (2000). Inhibition of surface spoilage bacteria in processed meats by application of antimicrobial films 
prepared with chitosan. International Journal of Food Microbiology, 62(1-2), 139-148. Retrieved from http://www.ncbi.nlm.nih.gov/pubmed/11139014.

European Parliament and Council (2008). REGULATION (EC) No 1334/2008 of the European Parliament and of the Council of 16 December 2008 on flavourings and certain food ingredients with flavouring properties for use in and on foods and amending Council Regulation (EEC) No 1601/91, Regulations EC. Official Journal of the European Union. Retrieved from http://eur-lex.europa.eu/legal-content/EN/ $\mathrm{TXT} / \mathrm{PDF} /$ ? uri $=$ CELEX:32008R1334\&from $=\mathrm{EN}$.

European Parliament and Council (2011). Commission regulation (EU) N ${ }^{\circ} 1129 / 2011$ of 11 November 2011 amending annex II to regulation (EC) $N^{\circ} 1333 / 2008$ of the European parliament and of the council by establishing a union list of food additives. Official Journal of the European Union, L295, 1-177.

Pereira, R. N., Souza, B. W. S., Cerqueira, M. A., Teixeira, J. A., \& Vicente, A. A. (2010). Effects of electric fields on protein unfolding and aggregation: Influence on edible films formation. Biomacromolecules, 11(11), 2912-2918.

Pintado, C., Ferreira, M., \& Sousa, I. (2009). Properties of whey protein-based films containing organic acids and nisin to control Listeria monocytogenes. Journal of Food Protection, 72(9), 1891-1896.

Pintado, C. M. B. S., Ferreira, M. A. S. S., \& Sousa, I. (2010). Control of pathogenic and spoilage microorganisms from cheese surface by whey protein films containing malic acid, nisin and natamycin. Food Control, 21(3), 240-246.

Rabea, E. I., Badawy, M. E.-T., Stevens, C. V., Smagghe, G., \& Steurbaut, W. (2003). Chitosan as antimicrobial agent: Applications and mode of action. Biomacromolecules, 4(6), 1457-1465.

Ramos, Ó. L., Pereira, J. O., Silva, S. I., Fernandes, J. C., Franco, M. I., Lopes-da-Silva, J. A., ... Malcata, F. X. (2012). Evaluation of antimicrobial edible coatings from a whey protein isolate base to improve the shelf life of cheese. Journal of Dairy Science, 95(11), 6282-6292.

Ramos, Ó. L., Santos, A. C., Leão, M. V., Pereira, J. O., Silva, S. I., Fernandes, J. C., ... Malcata, F. X. (2012). Antimicrobial activity of edible coatings prepared from whey protein isolate and formulated with various antimicrobial agents. International Dairy Journal, 25(2), 132-141.

Reps, A., Drychowski, L. J., Tomasik, J., \& Wiñnieswska, K. (2002). Natamycin in ripening cheeses. Pakistan Journal of Nutrition, 1(5), 243-247.

Robertson, G. L. (2006). Packaging of dairy products. In G. L. Robertson (Ed.). Food Packaging: Principles and Practice (pp. 524-525). Boca Raton: CRC press.

Robertson, G. L. (2013). Edible, biobased and biodegradable food packaging materials. In G. L. Robertson (Ed.). Food packaging - Principles and practice (pp. 49-90). Boca Raton: CRC press.

Rodriguez-Turienzo, L., Cobos, A., \& Diaz, O. (2012). Effects of edible coatings based on ultrasound-treated whey proteins in quality attributes of frozen Atlantic salmon (Salmo salar). Innovative Food Science \& Emerging Technologies, 14, 92-98.

Rojas-Grau, A. M., Soliva-Fortuny, R., \& Martìn-Belloso, O. (2009). Edible coatings to incorporate active ingredients to fresh- cut fruits: A review. Food Science E Tecnology, $20,438-447$.

Romero, V., Borneo, R., Passalacqua, N., \& Aguirre, A. (2016). Biodegradable films obtained from triticale ( $\mathrm{x}$ Triticosecale Wittmack) flour activated with natamycin for cheese packaging. Food Packaging and Shelf Life, 10, 54-59.

EFSA Scientific Committee (2011). Guidance on the risk assessment of the application of nanoscience and nanotechnologies in the food and feed chain EFSA scientific committee. EFSA Journal, 9(5), 1-36.

Seydim, A. C., \& Sarikus, G. (2006). Antimicrobial activity of whey protein based edible films incorporated with oregano, rosemary and garlic essential oils. Food Research International, 39(5), 639-644.

Soradech, S., Nunthanid, J., Limmatvapirat, S., \& Luangtana-anan, M. (2012). An approach for the enhancement of the mechanical properties and film coating efficiency of shellac by the formation of composite films based on shellac and gelatin. Journal of Food Engineering, 108(1), 94-102.

Ture, H., Eroglu, E., Ozen, B., \& Soyer, F. (2011). Effect of biopolymers containing natamycin against Aspergillus niger and Penicillium roquefortii on fresh kashar cheese. International Journal of Food Science \& Technology, 46(1), 154-160.

Ünalan, İ. U., Arcan, I., Korel, F., \& Yemenicioğlu, A. (2013). Application of active zeinbased films with controlled release properties to control Listeria monocytogenes growth and lipid oxidation in fresh Kashar cheese. Innovative Food Science \& Emerging Technologies, 20, 208-214.

Wang, L. Z., Liu, L., Holmes, J., Kerry, J. F., \& Kerry, J. P. (2007). Assessment of filmforming potential and properties of protein and polysaccharide-based biopolymer films. International Journal of Food Science \& Technology, 42(9), 1128-1138.

Westall, S., \& Filtenborg, O. (1998). Spoilage yeasts of decorated soft cheese packed in modified atmosphere. Food Microbiology, 15(2), 243-249.

Yangilar, F. (2016). Effect of the fish oil fortified chitosan edible film on microbiological, chemical composition and sensory properties of Göbek Kashar cheese during ripening time. Korean Journal for Food Science of Animal Resources, 36(3), 377-388.

Yangilar, F., \& Oğuzhan Yıldız, P. (2015). Casein/natamycin edible films efficiency for controlling mould growth and on microbiological, chemical and sensory properties during the ripening of Kashar cheese. Journal of the Science of Food and Agriculture, 96, 2328-2336 (January).

Yıldırım, M., Gulec, F., Bayram, M., \& Yıldırım, Z. (2006). Properties of Kashar cheese coated with casein as a carrier of natamycin. Italian Journal of Food Science, 18, 127-138.

Yilmaz, F., \& Dagdemir, E. (2012). The effects of beeswax coating on quality of Kashar cheese during ripening. International Journal of Food Science \& Technology, 47(12), 2582-2589.

Youssef, A. M., El-Sayed, S. M., El-Sayed, H. S., Salama, H. H., \& Dufresne, A. (2016). Enhancement of Egyptian soft white cheese shelf life using a novel chitosan/carboxymethyl cellulose/zinc oxide bionanocomposite film. Carbohydrate Polymers. 151, 9-19.

Zambrano-Zaragoza, M. L., Mercado-Silva, E., Del Real, L. A., Gutiérrez-Cortez, E., Cornejo-Villegas, M. A., \& Quintanar-Guerrero, D. (2014). The effect of nano-coatings with $\alpha$-tocopherol and xanthan gum on shelf-life and browning index of fresh-cut "red delicious" apples. Innovative Food Science \& Emerging Technologies, 22, 188-196.

Zambrano-Zaragoza, M. L., Mercado-Silva, E., Ramirez-Zamorano, P., Cornejo-Villegas, M. A., Gutiérrez-Cortez, E., \& Quintanar-Guerrero, D. (2013). Use of solid lipid nanoparticles (SLNs) in edible coatings to increase guava (Psidium guajava L.) shelf-life. Food Research International, 51(2), 946-953.

Zhong, Y., Cavender, G., \& Zhao, Y. (2014). Investigation of different coating application methods on the performance of edible coatings on mozzarella cheese. LWT - Food Science and Technology, 56(1), 1-8. 